\title{
SYSTEMS OF INNOVATIVE DEVELOPMENT OF MATHEMATICAL EDUCATION IN PRIMARY SCHOOLS
}

\author{
Alisher Sobirovich Abdusamatov \\ Teacher, "Department Of Primary Education", Termez State University \\ Khurshida Ibragimova \\ Student, Termez State University
}

\section{ABSTRACT}

The article discusses mathematical literacy in the framework of international assessment studies PISA, TIMSS and STEAM. In this direction, great importance is attached to the expansion of students' worldview, the development of consciousness and logical thinking, the formation of basic competencies and the work being done in this area.

KEYWORDS:- integration, PISA, TIMSS, STEAM, mathematical literacy, mathematical reasoning, method, methodology, mathematics, analysis, system, innovation, theory.

\section{INTRODUCTION}

According to the study and analysis of educational reforms, the process of updating teaching methods is very slow. When it comes to educational technologies and their essence, it should be noted that any method and methodology of teaching and learning is specific to the object of study. Also, the form, technology, teaching aids, methods and techniques of teaching in a particular subject are directly related to the age category of the students (e.g. lower grades, middle grades, upper grades, students). Therefore, in the development of teaching methods and techniques, it is necessary to take into account the specifics of the subject and the age category of students.

Integration is a source of new evidence that confirms or deepens students 'observations and conclusions in a variety of disciplines. They contribute to the development of students' knowledge through the exchange of various forms of activity.

Much attention is paid to the teaching of mathematics in the primary grades. The main purpose of this is to form in students a system of mathematical knowledge and skills necessary for life and to be able to function successfully in social activities, to form a person who can think clearly and fluently, critically and logically.

In today's era of globalization, PISA, PIRLS, TIMSS, STEAM, and many other studies that are recognized by the world community have developed international programs to assess student literacy. Launched in 1961, the Organization for Economic Cooperation and 
CURRENT RESEARCH JOURNAL OF PEDAGOGICS 2(5): 120-123, May

2021 DOI: https://doi.org/10.37547/pedagogics-crjp-02-05-21

ISSN 2767-3278

(C)2021 Master Journals

\section{Crossref dof 81 Google}

Accepted 25th May, 2021 \& Published 31 th May, 2021

Development (OECD) has been researching solutions to various financial problems over the past period. In particular, on the eve of the new century, international assessment studies have been developed on the basis of this organization in order to develop general secondary education, which is a key link in world education. The reason why the economic organization appeals to the field of education is that the staff for any field grows in schools, in ordinary classrooms. In this sense, a huge structure like the OECD will have to rank countries on how much they spend on the education system and how effective they are. Later, the interest of states in this research will increase and they will start participating in it.

In accordance with the Decree of the President of the Republic of Uzbekistan, the Concept of Development of the Public Education System until 2030 was adopted. Introduction of general education programs and new state educational standards, regular participation in international research programs to assess the level of knowledge of students, and in this regard, international research in the field of education quality assessment in the public education system of the Republic. It is aimed at the organization, establishment of international relations, comprehensive support and encouragement of research and innovation activities of students, first of all, the creative ideas and creativity of the younger generation.

\section{Materials AND METHODS}

When it comes to research in international assessment programs, each of these studies is focused on a specific area.

PISA is an international assessment program designed to assess students 'reading (comprehension), math, and science skills, and to assess students' knowledge and skills acquired during school years.
In PISA, monitoring the quality of students' knowledge is defined in 5 areas.

- Reading literacy

- Mathematical literacy

- Financial literacy

- Computer literacy

- Natural science literacy

The main task of the TIMSS international study is to make a comparative assessment of the school as a mathematics and science education. Every 4 years, the educational achievements of 4 th and 8th grade students are assessed, and at the same time, not only their knowledge and skills, but also their attitude to these subjects, interest, and allows you to compare motivation. This survey is conducted every 4 years.

In Modern Elementary Mathematics:

- The principle of purpose in the new Standards;

- Orientation of students' abilities to the goal;

- To mean that the factor "thinking", "search", "find" is more important than the factor "Knowledge";

- Ensuring the priority of imaginative and practical imaginative factors in educational practice;

- -discover undiscovered aspects and new opportunities for students;

- -create an environment for teachers and students to "think, reflect, create and explore new horizons";

- In the process of education, special attention should be paid to such factors as the approach to each lesson in terms of approach, technology, style, method.

STEAM educational technology is a new method of teaching school students, which is different 
CURRENT RESEARCH JOURNAL OF PEDAGOGICS 2(5): 120-123, May

2021 DOI: https://doi.org/10.37547/pedagogics-crjp-02-05-21

ISSN 2767-3278

(C)2021 Master Journals

\section{Crossref do) 81 Google}

Accepted 25th May, 2021 \& Published 31 ${ }^{\text {th }}$ May, 2021

from traditional teaching methods. It is designed to teach students five subjects at the same time: Science, Technology, Engineering, Fine Arts, and Mathematics. Keep in mind that these trends are becoming the most popular in the modern world. That is why today the STEAM system is evolving as one of the main trends. STEAM is based on the application of the educational direction and practical approach, as well as the integration of all five areas into a single education system. [3]

The purpose of categorizing methodological innovations is considered to be useful in determining the order and sequence of their application. However, it should be noted that innovations are divided into types only conditionally. Because most methodological innovations are multifaceted. Also, the concept of a system of methodological innovations develops in accordance with the periodic requirements for education, and improvement takes place in an individual and person-centered environment. That is, the basic methodological question in elementary mathematics education is: "Who will teach?", "Who will teach?" is of great importance.

As we have seen, each educational technology has its own direction. But the idea is the same: to bring up the younger generation to be mature, spiritually and physically healthy. If we look at PISA, TIMSS and STEAM technologies, each of them has mathematical literacy. What is math literacy?

Mathematical literacy is the ability of a person to think mathematically about different life situations (contexts) and problems, to express a given problem with the help of mathematics, to apply mathematics in solving a problem and to use the results to interpret and evaluate the solution of a problem. It includes concepts, algorithms, facts, and tools for describing, explaining, and predicting events. It helps people understand the place of mathematics in the universe and make informed judgments and decisions that are necessary for creative, curious, and self-analyzing 21st century citizens [4].

If we look at the definition of mathematical literacy, it requires the effective use of mathematics in solving real-life problems given in different contexts. However, mathematical literacy, whether inductive or deductive, requires the student to perform mathematical reasoning and to use mathematical concepts, facts, algorithms, and tools to describe, explain, and predict events, and to solve problems. Mathematical literacy assesses skills in 8 main areas:

1. Critical thinking;

2. Creativity;

3. Research and analysis;

4. Independence, initiative and determination;

5. Use of data;

6. Systematic thinking;

7. Communication;

8. Meditation.

Mathematical literacy refers to solving problems using mathematics on the one hand, and mathematical reasoning on the other. Mathematical reasoning and problem solving are types of students' mental activities.

\section{Conclusion}

Mathematical reasoning:

- draw simple conclusions;

- $\quad$-choose the appropriate justification;

- $\quad$-explain whether the mathematical result or conclusion is meaningful, depending on the content of the problem;

- -expression of the problem in another form, including its adaptation to mathematical concepts and making appropriate 
assumptions;

- -application of definitions, rules and formulas, algorithms and calculations;

- substantiate a mathematical model that is realistic and constructed;

- -explain and justify the processes and algorithms, models used to determine the mathematical result or solution;

- -determine the boundaries of the model to solve the problem;

- -think on mathematical facts in explaining and justifying the mathematical result;

- -critical review of the limitations of the model designed to solve problems;

- -interpretation of mathematical results in the context of the real world to explain the meaning of the results;

- -explain the connections between symbolic and formal languages, which are necessary for the presentation of the problem in the context and its mathematical expression;

- -create explanations and arguments that support and reject the mathematical solution of the problem in the context, and think about the solution of the mathematical solution;

- -analysis of similarities and differences between a mathematical problem and its computational model;

- -explain the use of simple algorithms and identify and eliminate errors in them [4].

Mathematical reasoning, whether deductive or inductive, has to do with some of the basic concepts that form the basis of school mathematics. Mathematical literacy is a type of mental activity in which students are assessed, based on the above-mentioned reasoning.

In conclusion, it should be noted that if the above-mentioned International Studies, Mathematical Considerations and Mathematical Literacy are applied to assignments, it will be possible to study the basics of disciplines in a specific area. Conducting such international research is an important factor not only for human development but also for the development of the state.

\section{REFERENCES}

1. Methods of teaching mathematics in primary school. L.Sh.Levenberg, G'.Ahmadjonov, A.N.Nurmatov. Tashkent "Teacher" 1985.

2. To prepare students for international research. newsletter No. 1. Tashkent-2020

3. Assessment of students' mathematical literacy in international research. A.A.Ismailov, N.A.Karimov, B.Q.Haydarov, Sh.N.Ismailov. "East". Tashkent-2019

4. Arnold V.I. "Female and soft" mathematical models. M: MCNMO, 2000.32s

5. Morkovich AG Conversations with teachers of mathematics: Textbook method. Manual \ A.G. Mordkovich. - 2nd ed., Add. And reworked. - M: LLC "Izatelstvo Onyx": LLC "Publishing house Mir and Education", 2008. - 336s

6. Approach NS. Meta-methodic approach to the educational process // Modern scienceintensive technologies -№6. 2004. 14-16 pp.

7. Farfieva K. A. Social Media as a factor in formation of scientific thinking in youth. European Journal of Research and Reflection in Educational Sciences. Vol. 8 No. 10, 2020. Pp. 52-56. 